\title{
Is the routine drainage after surgery for thyroid necessary? - A prospective randomized clinical study [ISRCTN63623 I53] Jotinder Khanna ${ }^{1,3}$, RS Mohil1,3, Chintamani*1,3,4, Dinesh Bhatnagar ${ }^{1,3}$, MK Mittal ${ }^{1,3}$, M Sahoo ${ }^{2,3}$ and Magan Mehrotra ${ }^{1,3}$
}

Address: ${ }^{1}$ Department of Surgery, Institute of Nuclear Medicine and Allied Sciences, Delhi, India, ${ }^{2}$ Department of Cytopathology, Institute of Nuclear Medicine and Allied Sciences, Delhi, India, ${ }^{3}$ Vardhman Mahavir Medical College Safdarjang Hospital, New Delhi-India and ${ }^{4}$ Department of Radiology, Institute of Nuclear Medicine and Allied Sciences, Delhi, India

Email: Jotinder Khanna - jotinderkhanna@rediffmail.com; RS Mohil - rsmohil@yahoo.com; Chintamani* - chintamani7@rediffmail.com; Dinesh Bhatnagar - drdineshbhatnagar@yahoo.com; MK Mittal - chintamani@doctor.com; M Sahoo - manu@scientist.com;

Magan Mehrotra - maganmagan@rediffmail.com

* Corresponding author

Published: 19 May 2005

BMC Surgery 2005, 5:II doi:10.1 I86/1471-2482-5-II
Received: 13 November 2004

Accepted: 19 May 2005

This article is available from: http://www.biomedcentral.com/I47I-2482/5/II

(C) 2005 Khanna et al; licensee BioMed Central Ltd.

This is an Open Access article distributed under the terms of the Creative Commons Attribution License (http://creativecommons.org/licenses/by/2.0), which permits unrestricted use, distribution, and reproduction in any medium, provided the original work is properly cited.

\begin{abstract}
Background: Drains are usually left after thyroid surgery to prevent formation of hematoma and seroma in the thyroid bed. This is done to reduce complications and hospital stay. Objective evaluation of the amount collected in the thyroid bed by ultrasonography (USG) can help in assessing the role of drains.
\end{abstract}

Methods: A randomized prospective control study was conducted on 94 patients undergoing 102 thyroid surgeries, over a period of fifteen months. Patients included in the study were randomly allocated to drain and non-drain group on the basis of computer generated random number table. The surgeon was informed of the group just before the closure of the wound Postoperatively USG neck was done on first and seventh postoperative day by the same ultrasonologist each time. Any swelling, change in voice, tetany and tingling sensation were also recorded. The data was analyzed using two-sample t-test for calculating unequal variance.

Results: Both groups were evenly balanced according to age, sex, and size of tumor, type of procedure performed and histopathological diagnosis. There was no significant difference in collection of thyroid bed assessed by USG on DI \& D7 in the two groups $(p=0.3 \mid 3)$ but the hospital stay was significantly reduced in the non-drain group $(p=0.007)$. One patient in the drain group required needle aspiration for collection in thyroid bed. No patient in either group required re-operation for bleeding or haematoma.

Conclusion: Routine drainage of thyroid bed following thyroid surgery may not be necessary. Not draining the wound results in lesser morbidity and decreased hospital stay.

\section{Background}

Most surgeons give into tradition of leaving a drain following thyroid surgery with the hope that this will oblit- erate the dead space and evacuate collected blood and serum. This belief is further reinforced by the fact that postoperative drains usually yield fluid. The need for 
drainage has been questioned after various types of surgeries with much larger potential dead spaces like cholecystectomy and colonic anastamosis [1,2]. These procedures are now routinely not drained. Blood and serum that they are supposed to drain usually block drains. They add to discomfort, give extra scar and increase hospital stay. We carried out a prospective randomized study to study the role of drains after thyroid surgery and monitor the fluid collection in thyroid bed objectively by USG.

\section{Methods}

The approval was taken from the reviewer board and ethical committee of the hospital before initiating the study and informed consent was taken from the patients regarding the use of drains. The study was carried out on 94 patients who underwent 102 thyroid surgeries in a single unit between January 2001 and March 2002. This discrepancy was due to 8 patients undergoing completion thyroidectomies for well differentiated thyroid carcinomas confirmed by histopathology.. These 8 patients were randomized as fresh cases with no consideration given to previous surgery. Patients with cervical lymph nodes metastases requiring neck dissection and those with clinical or laboratory indicators of coagulation disorders were excluded from the study. No patient was excluded on the basis of size of the gland, difficulty in surgery, surgery involving both lobes and re-operation in the neck. Alll patients underwent routine preoperative and postoperative laryngoscopy(indirect/direct) as a part of the protocol at our center. The patients were randomly allocated to drain and non-drain group on the basis of computer generated random number table. The operating surgeon was informed of the group just before the closure of the wound. In the drain group a closed suction drain with negative pressure (Romovac ${ }^{\varpi}$ ) was brought out through a separate wound. Ultra sound of the neck using B mode with linear frequency of $7.5 \mathrm{MHz}$ was performed in both groups between $24-48$ hours of surgery and seventh postoperative day each time by the same radiologist or under his supervision. Volume of fluid collection in the operative bed was calculated by measuring the maximum diameter in three dimensions. The volume of fluid collected in the suction drain was measured separately. The drains were removed in all the patients after 48 hours. Before the present study was contemplated, a pilot study was carried out on 20 patients(excluded from the present study)to ascertain the duration of drainage and the drains were removed after the drainage reduced to less than 30 $\mathrm{ml}$ in 24 hours following which the patients were discharged. It was observed that the average time taken for the drains to be removed was 4 days while the ultrasound assessment did not reveal any collection in the thyroid bed after 48 hours. The review committee of the hospital therefore recommended keeping of the drains for 48 hours in order to compare the morbidity in the two groups. Therefore a cut off period of 48 hours for removal of drains was considered. All patients were observed for any postoperative respiratory distress, change in voice, wound collection, tingling sensation and tetany. The specimens were subjected to histopathological examination for final confirmation of diagnosis. Using two sample " $t$ " test all the data was statistically analyzed for any significant difference in the two groups for a) fluid collection in thyroid bed on day one and day seven, b) size of nodule and amount of fluid collection and c) complication rate.

\section{Results}

The average age of patients in the present study was 34.56 years (range $8-60$ years). Male to female ratio was $1: 6.84$, with equal distribution in both the groups based on the type of surgery and size of nodule. The amount of fluid collection in thyroid bed as assessed by USG for both the groups on day one and day seven is shown in Table 1 . Two-sample T- test was applied for detecting any difference in means of fluid collected between the two groups. There was no statistically significant difference in the volume of fluid collection on day one $(\mathrm{p}=0.371)$ and day seven $(p=0.577)$ between the two groups. On the other hand the amount of fluid collected in the suction drain was noted for 48 hours. The average collection was 167.14 $\mathrm{ml}$ (range $30-120 \mathrm{ml} /$ day).

Table I: Volume of fluid collection in the two groups as assessed by USG on D I \& D7

\begin{tabular}{|c|c|c|c|c|}
\hline \multirow[t]{2}{*}{ Amount of fluid } & \multicolumn{2}{|c|}{ Drain group } & \multicolumn{2}{|c|}{ Non drain group } \\
\hline & DI & D7 & DI & D7 \\
\hline Mean & $3.258 \mathrm{ml}$ & $1.819 \mathrm{ml}$ & $2.345 \mathrm{ml}$ & $1.366 \mathrm{ml}$ \\
\hline Minimum & $0 \mathrm{ml}$ & $0 \mathrm{ml}$ & $0 \mathrm{ml}$ & $0 \mathrm{ml}$ \\
\hline Maximum & $40 \mathrm{ml}$ & $35 \mathrm{ml}$ & $19 \mathrm{ml}$ & $14.2 \mathrm{ml}$ \\
\hline Total number of patients & 51 & 51 & 51 & 51 \\
\hline \multicolumn{5}{|c|}{ Two sample $T$ test for detection of difference in means of fluid collected on DI \& DD7 respectively } \\
\hline Unequal variance & $\mathrm{T}$ & DF & $\mathrm{P}$ & \\
\hline DI & 0.9 & 81.5 & 0.371 & \\
\hline D7 & 0.58 & 72.9 & 0.577 & \\
\hline
\end{tabular}


Table 2: Chi Squared approximation for difference in volume of collection based on size on DI

\begin{tabular}{|c|c|c|c|c|}
\hline \multirow[t]{2}{*}{ Amount of fluid in $\mathrm{ml}$} & \multicolumn{2}{|c|}{ Drain group } & \multicolumn{2}{|c|}{ Non drain group } \\
\hline & $<4 \mathrm{~cm}$ & $>4 \mathrm{~cm}$ & $<4 \mathrm{~cm}$ & $>4 \mathrm{~cm}$ \\
\hline Mean DI & $2.30 \mathrm{ml}$ & $5.935 \mathrm{ml}$ & $2.452 \mathrm{ml}$ & 2.011 \\
\hline Total number of patients & 37 & 14 & 34 & 17 \\
\hline
\end{tabular}

$P=0.313$ (ns)

Table 3: Chi Squared approximation for difference in volume of collection based on size on D7

\begin{tabular}{lllll}
\hline Amount of fluid & \multicolumn{2}{c}{ Drain group } & \multicolumn{2}{c}{ Non drain group } \\
\cline { 2 - 5 } & $<4 \mathrm{~cm}$ & $>4 \mathrm{~cm}$ & $<4 \mathrm{~cm}$ & $>4 \mathrm{~cm}$ \\
\hline Mean & $0.956 \mathrm{ml}$ & $1.956 \mathrm{ml}$ & $1.388 \mathrm{ml}$ & $1.244 \mathrm{ml}$ \\
Total number of patients & 37 & 14 & 34 & 17
\end{tabular}

$P=0.0712(n s)$

Table 4: Distribution of complications into drain and non-drain group

\begin{tabular}{lll}
\hline Complication & Drain group & Non drain group \\
\hline Swelling & 3 & 3 \\
Tetany & 0 & 2 \\
Tingling & 1 & 2 \\
Infection & 1 & 1 \\
\hline
\end{tabular}

Average size of thyroid nodule was $4.03 \mathrm{~cm} \& 4.12 \mathrm{~cm}$ in the drain and non-drain groups respectively. Kruskal Wallis one way non parametric analysis showed no significant statistical difference in the amount of collection according to size of nodule arbitrarily taken as $<4 \mathrm{~cm} \&>$ $4 \mathrm{~cm}$ on D1 \& D7 respectively (Table $2 \& 3$ ).

Average duration of hospital stay was 3.715 days for the entire group; 4.35 days for drain group and 3.07 days for non-drain group. This was statistically significant when analysed using two-sample T test $(\mathrm{P}=0.0072)$.

Complications that were observed in the present study are shown in Table 4. Of the six patients who developed collection, four had undergone bilateral subtotal thyroidectomy with an average amount $13.40 \mathrm{ml}$. Only one patient from the drain group required single aspiration. None of the patients had respiratory distress. Three patients had tingling sensation and two patients developed transient tetany. Five patients developed transient change in voice four of these belonged to drain group, the difference being non significant $(\mathrm{p}=0.36)$. One patient in each group developed wound infection. The presence or absence of drains, expectedly did not contribute significantly to the postoperative complications.

\section{Discussion}

Drains have been traditionally used in most of the surgical procedures with limited evidence to suggest any benefit [1-4]. The present prospective randomized study has failed to show any advantage of routinely using drain after uncomplicated thyroid surgery. Except for patients undergoing simultaneous neck dissection or coagulation disorder no other exception was made based on factors mentioned above.

Other authors in randomized studies reported similar results with sample size varying from 100 to 200 patients $(5-10)$. Two large non-randomized studies of 250 and 400 patients have also documented no benefit of using drains after thyroid surgery $[11,12]$. Objective assessment of fluid collection in thyroid bed by USG has been done very infrequently in randomized settings. Debry et al have used it selectively in two patients developing postoperative haematoma while Schwartz used it to compare two types of drains $[5,13]$. In the present study absence of fluid in the thyroid bed on USG but its presence in the suction drain could therefore be due to the drain itself [8]. The drains by virtue of the inflammation induced due to their presence may actually increase the drainage. The vaccum created by the negative suction of the drain may prevent the lymphatics from sealing off and thus cause increase in the seroma formation and drainage [5-9].

\section{Conclusion}

The present randomized study highlights that placement of drains after routine thyroid surgery may induce rather than prevent fluid collection, is not related to the type of surgery or size of nodule, has no influence on complications, leads to an extra scar and may increase the hospital stay (if the patients can not be discharged with drains in situ). Meticulous haemostasis and attention to finer details during surgery are more important. Routine use of drains after thyroid surgery may therefore not be necessary.

\section{Competing interests}

The author(s) declare that they have no competing interests.

\section{Authors' contributions}

DB was the chief surgeon in charge of the unit, the department of surgery also responsible for the designing of the 
study, RSM, CM were the senior operating surgeons, JK, $\mathrm{MM}$ were the senior residents in charge of the cases did the statistical analysis, MK did the ultrasonographic assessment and MS was responsible for the pathological analysis. All authors read and approved the manuscript.

\section{Acknowledgements}

We would like to acknowledge with gratitude the contribution of Dr Rajvir Singh PhD (Biostatistics) Statistician All India Institute Of Medical sciences for the statistical analysis.

\section{References}

I. Lewis RT, Goodall RG, Marien B, Park M, Llyod-Smith W, Weigand FM: Simple elective cholecystectomy; to drain or not. Am J Surg 1990, 159:242-245

2. Hoffmann J, Lorentzen M: Drainage after cholecystectomy. $\mathrm{Br} \mathrm{J}$ Surg 1985, 72:423-427.

3. Hoffmann J, Shokouh-Amiri M, Damm P, Jensen R: A prospective controlled study of prophylactic drainage after colonic anastomoses. Dis colon rectum 1987, 30:449-452.

4. Johnson CD, Lamont PM, Orr N, Lennox M: Is drain necessary after colonic anastomosis? JR Soc Med I989, 82:66I-664.

5. Debry C, Renou G, Fingerhut A: Drainage after thyroid surgery: a prospective randomised study. The Journal of Laryngology and Otology 1999, I | 3:49-5I.

6. Peix JL, Teboul F, Feldman H, Massard JL: Drainage after thyroidectomy: a randomized clinical trial. Int surg 1992, 77: 122-124.

7. Ayyash K, Khammash M, Tibblin MS: Drain Vs no drain in primary thyroid and para thyroid surgery. European Journal of Surgery I991, I57:II3-II4.

8. Wihlborg $\mathrm{O}$, Bergljung $\mathrm{L}$, Matensson $\mathrm{H}$ : To drain or not to drain in thyroid surgery. a controlled clinical study. a controlled clinical study. Archives of surgery 1988, 1 23:40-4I.

9. Kristofferson A, Sandzen B, Jarhult J: Drainage in uncomplicated thyroid and para thyroid surgery. Br J Surg 1986, 73: I2I-I22.

10. Schoretsanitis G, Melisas J, Sanidas E, Christodoulakis M, Vlachonikolis JG: Does draining the neck affect morbidity following thyroid surgery? Am surgeon 1998, 64:778-780.

II. Shaha AR, Jaffe BM: Selective use of drain in thyroid surgery. Journal of Surgical Oncology 1993, 52:24I-243.

12. Arriyanayagam DC, Narayan Singh V, Busby D, Sieunarine K, Raju G: Thyroid surgery without drainage; I 5 years of clinical experience. Journal of Royal College of Surgery Edinburgh 1993, 38:69-70.

13. Schwartz W, Willy, Ndzee C, Gerugross H: Gravity or suction drainage in thyroid surgery? Control of efficacy with ultrasound determination of residual haematoma. Archives of Surgery 1996, 381:337-342.

\section{Pre-publication history}

The pre-publication history for this paper can be accessed here:

http://www.biomedcentral.com/1471-2482/5/11/prepub

\section{Publish with Biomed Central and every scientist can read your work free of charge}

"BioMed Central will be the most significant development for disseminating the results of biomedical research in our lifetime. "

Sir Paul Nurse, Cancer Research UK

Your research papers will be:

- available free of charge to the entire biomedical community

- peer reviewed and published immediately upon acceptance

- cited in PubMed and archived on PubMed Central

- yours - you keep the copyright

Submit your manuscript here:

http://www.biomedcentral.com/info/publishing_adv.asp
BioMedcentral 